STUDIA UBB PSYCHOL.-PAED., LXVI, 2, 2021, p. 5 - 38

(Recommended Citation)

DOI:10.24193/subbpsyped.2021.2.01

\title{
SOCIAL AND PSYCHOLOGICAL CORRELATES OF THE MAJOR SOURCES OF DISCOMFORT PERCEIVED BY STUDENTS IN THE COVID-19 PANDEMIC: AN EXPLORATORY STUDY ON A ROMANIAN SAMPLE
}

\author{
ÉVA KÁLLAY1a, SEBASTIAN PINTEAª
}

\begin{abstract}
The COVID-19 pandemic has a significant impact on the physical and psychological functioning of the entire world's population. Our study has had three major aims: (1) to identify the major sources of discomfort related to COVID-19 pandemic in third year psychology students, (2) to establish a hierarchy of the major sources of discomfort, and (3) to identify possible vulnerabilities for different sources of discomfort. We used a cross-sectional study to explore more accurately the individual reactions and possible vulnerabilities, also including open-ended questions to explore perceived sources of discomfort.

Our study included 289 third-year psychology students from Babeș-Bolyai University in Cluj-Napoca, Romania ( $M=24.39$ years, $S D=7.12$ ). All participants were assessed regarding their levels of: depression, narcissistic traits, perfectionism, perceived stress, self-esteem, intolerance of uncertainty, subjective well-being, and emotion regulation strategies.

Our results indicate significant gender and age differences: male participants reported mobility restrictions as a source of discomfort more frequently than female participants, and younger students are less concerned with restrictions regarding social relations, while older students report less emotional
\end{abstract}

${ }_{1}$ PhD, Department of Psychology, Babes-Bolyai University, Cluj-Napoca, Romania, str. Republicii $n r$. 37, 400015, Cluj-Napoca, Romania.Email: evakallay@psychology.ro

2 PhD, Department of Psychology, Babes-Bolyai University, Cluj-Napoca, Romania, str. Republicii $n r$. 37, 400015, Cluj-Napoca, Romania. Email: sebastianpintea@psychology.ro

a The authors had equal contributions to this study. 
ÉVA KÁLLAY, SEBASTIAN PINTEA

problems and less concern with educational problems. Students living in urban areas report less emotional problems than students from rural areas. The results generated by our research point out certain social and psychological vulnerabilities for each perceived source of discomfort (emotion-regulation strategies, perfectionism, narcissism), can bring a valuable input in counselling and therapy for individuals who are maximally affected by the pandemic of COVID-19.

Keywords: COVID-19 pandemic, psychological discomfort, vulnerabilities, students

\section{Introduction}

Due to its extremely rapid spread, by March 2020, COVID -19 was declared by WHO as being a worldwide pandemic, and the situation quickly became an extremely serious public health problem (Phelan, Katz, \& Gostin, 2020; Vergara-Buenaventura, Chavez-Tuñon, \& Castro-Ruiz, 2020; WHO, 2020).

Previous research indicated that the psychological reactions of the population to the implications of pandemics play a crucial role both in the physical spreading of the disease and the isolation of the infection, and may affect the individuals' functioning on the intra- and interpersonal level (Taylor, 2019). Pandemics and their implications are frequently associated with intense feelings of uncertainty and confusion regarding the infection's duration and effects on health, emotional functioning, economy, thus generating intense levels of distress, anxiety and fear in all layers of the population (Bao, Sun, Meng, Shi, \& Lu, 2020; Peteet, 2020; Wang, Pan, Wan, Tan, Xu, Ho, et al., 2020). Moreover, the death of family members, friends and loved ones can be easily perceived as traumatic (Taylor, 2017).

The institution of quarantine and its sources of discomfort (e.g., separation from loved ones, the possible overwhelming of health-care systems, loss of freedom to travel, shortage of food and financial resources, disruptions of usual life-routines, closure of schools, changing work habits, etc.) further aggravate the initial stressors, significantly affecting the populations' emotional and mental 
SOCIAL AND PSYCHOLOGICAL CORRELATES OF THE MAJOR SOURCES OF DISCOMFORT PERCEIVED ...

well-being (Brooks, Webster, Smith, Woodland, Wessely, Greenberg, \& Rubin, 2020; Shultz, Espinel, Flynn, Hoffmann, \& Cohen, 2008; Smith, Keogh-Brown, Barnett, 2011; Vergara-Buenaventura et al., 2020). Because quarantined and highly stressed individuals cannot always efficiently fulfill their occupational and personal duties, national economies and social infrastructures may also be significantly affected (Shultz, Baingana, \& Neria, 2015). Studies investigating the short- and long-term effects of pandemics sustain that in most cases the "psychological footprint" would leave deeper imprints than the actual "medical footprint" (Shutz et al., 2008; Taylor, 2019). In other words, the psychological impact and afferent cost might exceed the medical ones.

Naturally, literature has investigated risk and protective factors in face of such extended adversities as pandemics. Thus, negative emotionality (neuroticism), trait anxiety, intolerance of uncertainty, unrealistic optimism, emotion regulation (Huang et al., 2016; Lauriola et al., 2018; O’Bryan \& McLeish, 2017; Rosser, 2018; Shepperd, Waters, Weinstein, \& Klein, 2015; van Dijk et al., 2016) all proved to be subjacent factors that are significantly involved in the individuals' reactions towards extended adversities.

An increasingly large number of studies have indicated that the psychological consequences of the COVID-19-generated crisis are multiple: increasing depressive symptoms, anxiety, PTSD, insomnia, lowered levels of well-being, confusion, etc. have been reported in studies conducted all over the world during the COVID-19 pandemic (Fernández-Abascal \& Martín-Díaz, 2021; Gao, Zheng, Jia, Chen, Mao, Chen, et al., 2020; González-Sanguino, Ausín, Castellanos, Saiz, López-Gómez, \& Muñoz, Liu, Zhu, Fan, Makamure, Zheng, \& Wang, 2020; Ntella, Giannakas, Giannakoulis, Papoutsi, \& Katsaounou, 2020; Zhu, Sun, Zhang, Wang, Fan, Yang, et al., 2020).

Furthermore, there is a plethora of research investigating the effects of the COVID-19 pandemic on different populations (e.g., general population, children, older adults, medical staff), and different areas of functioning (intimacy in couples, economy, mass media, etc.) (Anwar, Malik, Raees, \& Anwar, 2020; Eurostat, 2020; OECD, 2020a, b; Fegert \& Schulze, 2020; ILO, 2020; Mercier, Arquizan, \& Roubille, 2020; Panzeri, Ferrucci, Cozza, \& Fontanesi, 2020; Williamson, 2020; Yang, Li, Zhang, Zhang, Cheung, \& Xiang, 2020). However, there is a reduced number of studies investigating the impact of the present 
COVID-19 pandemic on the psychological functioning of university students, although this is a vulnerable population to mental health problems (Blanco, Okuda, Wright, Hasin, Grant, Liu, et al., 2008) especially if we take into consideration the fact that these youngsters have to simultaneously face the transition from adolescence to adulthood (Husky, Kovess-Masfety, \& Swendsen, 2020).

In normal, non-pandemic life conditions, emotional and mental wellbeing are strongly related to students' academic achievements and success (Esch, Bocquet, Pull, Couffignal, Lehnert, Graas, Fond-Harmant, \& Ansseau, 2014; Fletcher, 2010), also affecting motivation, implication, concentration, social relationships, etc. (Unger, 2007). Research also indicates that due to developmental characteristics, adolescents and young adults may be seriously affected not only by the inherent life-threatening aspects of different highly-stressful situations, but also by the resulting social restrictions as well (Fegert \& Schulze, 2020). Thus, it became extremely important to investigate the specificities of psychological reactions due to the COVID-19 pandemic in student populations (Cao, Fang, Hou, Han, Xu, Dong, \& Zheng, 2020).

Previous research conducted in non-pandemic life-situations indicated that high levels of perfectionism (on all three dimensions: self-oriented, other oriented and socially prescribed perfectionism) may obstruct the healthy adaptation processes to stressful situations (Hewitt \& Flett, 2001; Fry \& Debats, 2009; Smith, Sherry, Gautreau, Mushquash, Saklofske, \& Snow, 2017). Perfectionism was defined as a personality trait in which the person strives to achieve extremely high standard performances, and evaluates the results of his/her and others' achievements in an excessively critical way (Flett \& Hewitt, 2002).

Similar results were produced by research investigating narcissistic traits (a "pervasive pattern of grandiosity (in fantasy or behavior), a constant need for admiration, and a lack of empathy" (American Psychiatric Association, 2013), especially in the younger generations (Bradlee \& Emmons, 1992; Kasser \& Ryan, 1996; Dickinson \& Pincus, 2003; Sherry, Gralnick, Hewitt, Sherry, \& Flett, 2014; Twenge \& Campbell, 2007). Optimal levels of self-esteem have been shown to have protective effect in adjustment and adaptational processes (Friedlander, Reid, Shupak, \& Cribbie, 2007; Mooney, Sherman, \& Lo Presto, 1991). 
SOCIAL AND PSYCHOLOGICAL CORRELATES OF THE MAJOR SOURCES OF DISCOMFORT PERCEIVED ...

Furthermore, literature indicated that specific stress related reactions (depressive and anxious symptoms) may be traced back to a cluster of several types of emotion regulation strategies ("what people think after having experienced a negative or traumatic event" (Garnefski, Kraaij, \& Spinhoven, 2001, p. 7) (Garnefski, van den Kommer, Kraaij, Teerds, Legerstee, \& Onstein, 2002). For instance, positive refocusing, positive reappraisal, acceptance, putting into perspective have been considered as adaptive strategies, while rumination, catastrophizing, other blame with reduced levels of emotional well-being (Carver, Scheier, \& Weintraub, 1989; Nolen-Hoeksema, Parker, \& Larson, 1994; Sullivan, Bishop, \& Pivik, 1995; Tennen \& Affleck, 1990). Consequently, our study has three major objectives:

a. To identify the major sources of discomfort related to COVID-19 pandemic in third year psychology students

b. To establish a hierarchy of the major sources of discomfort

c. To identify possible vulnerabilities for different sources of discomfort

The design of our study is cross-sectional. In order to explore more accurately the individual reactions and possible vulnerabilities, and to go beyond the limits imposed by the limitations of closed-ended questions, we added also a qualitative component, in which, by using several open-ended questions, we gathered free answers and performed a thematic analysis upon them.

\section{Method}

\section{Participants}

The reasons why our study involved only students of psychology are manifold: first of all, since both authors teach at the department of psychology, through extensive discussions with them, we became familiar with their major sources of discomfort, and considered that including open-ended questions could better explore their perceived sources of discomfort. Secondly, since our students have both theoretical and practical formation during their formative 
years, which strongly determine the quality and depth of their knowledge-base, we considered that the investigation of this population is highly important. In this way we would have obtained relevant information which could further on significantly contribute to the development of specific prevention and intervention strategies, through which we could offer our students better conditions in such challenging times to enhance their overall psychological well-being and academic performances.

Using $G^{*}$ Power 3.1.9.4, with $\alpha=0.05,1-\beta=0.85$ and an effect size $r=0.18$, the minimum number of participants generated was $\mathrm{N}=271$ for a two-tail test. Our study included a convenience sample of 289 participants, third-year psychology students from Babeș-Bolyai University in Cluj-Napoca, Romania. The minimum age of the participants was 20 years, while the maximum 58, with a mean age of 24.39 years (SD=7.12). Of the 298 participants 39 were male (13.5\%), and 250 female students (86.5\%). Participants were assessed in AprilMay 2020 during the lockdown in Romania. The collection of the data has started after the investigators have obtained the agreement of the Ethical Committee of Babes-Bolyai University, Cluj-Napoca, Romania (Nr. 6643/11.05.2020). After providing informed consent, participants completed an on-line questionnaire packet that took 45 minutes to fill.

\section{Instruments}

Demographic variables were: age, gender, residence and marital status.

Depression tendencies were measured with the Beck Depression Inventory-II (BDI, Beck, Rush, Shaw \& Emery, 1979; Romanian adaptation David \& Dobrean, 2012). The BDI is a 21 -item, multiple-choice format inventory, designed to measure the presence of depression in adults and adolescents. Each of the 21 items assesses a symptom or attitudes specific to depression, inquiring its somatic, cognitive and behavioral aspects. By its assessments, single scores are produced, which indicate the intensity of the depressive episode. Scores ranging from 0 to 9, represent normal levels of depression, 10-18= mild 
to moderate depression; $19-29=$ moderate to severe depression, scores above $30=$ severe depression. Internal consistency indices of the BDI are usually above .90. For the present sample, the internal consistency for the BDI was .85 .

Narcissistic traits were measured with 16-item Narcissistic Personality Inventory (NPI-16, Ames, Rose, \& Anderson, 2006; translated and adapted into and Romanian by the authors) derived by the authors from the long, 40-item NPI scale (Raskin \& Hall, 1979). The test consists of sixteen pairs of statements, and for each pair subjects should select the one that they feel best reflect their personality. The NPI-16 is a short measure of subclinical narcissism, presenting a good face, internal, discriminative, and predictive validity (Ames et al., 2006). The internal consistency of the NPI-16 for the present sample was .81 .

Perfectionism was measured with the 45-item self-report Multidimensional Perfectionism Scale (MPS, Hewitt \& Flett, 2002; translated and adapted into Romanian by the authors). The MPS contains three sub-scales: self-oriented perfectionism (SOP) (e.g., "One of my goals is to be perfect in everything I do"), other-oriented perfectionism (OOP) (e.g., "Everything that others do must be of top-notch quality"), and socially-prescribed perfectionism (SPP) (e.g., "I find it difficult to meet others' expectations of me"). Responses are given on a 7-point Likert scale, from 1 (strongly disagree) to 7 (strongly agree). The psychometric properties of the scale (reliability and validity) were found across studies to be very good (Hewitt et al., 2003). Cronbach's alpha for the present sample ranged from .74 to .87 .

Stress was measured with the Perceived Stress Scale (PSS, Cohen, Kamarck, \& Mermelstein, 1983; translated and adapted into Romanian by the authors). The PSS measures the degree to which situations in one's life are appraised as stressful. Items were designed to tap how unpredictable, uncontrollable, and overloaded respondents find their lives. The PSS is a 14-item self-report questionnaire, with answers being rated on a 5-pointLikert scale ( 0 -never, 4-very often). Cronbach's alpha for the present sample was .81. 
Self-esteem was measured with Rosenberg's (SES, Rosenberg, 1979) 10-item Self-Esteem Scale. The scale is comprised of 10 statements, each focusing on general feelings, perceptions of the self. Participants are asked to answer each statement on a four-point Likert scale (1=agree not at all, 4=agree completely). The SES demonstrated high levels of reliability and validity. Cronbach's alpha for the present sample was .85 .

Intolerance of Uncertainty was assessed with the 12-item version of the Intolerance of Uncertainty Scale (IUS-12) (Carleton et al., 2007). The IUS-12 permits the calculation of total scores, as well scores on the Prospective Anxiety and the Inhibitory Anxiety Subscale. Participants are asked to answer the 12 items on a five-point Likert-type scale (1=not at all characteristic of me; $5=$ entirely characteristic of me). Total scores range from 12 to 60 . The IUS-12 demonstrated a high internal consistency in undergraduate samples (IUS-12: $\alpha=.91$, Carleton et al., 2007). Internal consistency of the IUS-12 in the current sample was also high $(\alpha=.92)$.

Subjective well-being was assessed with the 5-item WHO well-being questionnaire (WHO Collaborating Centre in Mental Health, 1999), scale that focuses the assessment of positive affective states. Items are rated on a 6-point Likert scale from 0 (not present) to 5 (constantly present). Scores are summed, with raw scores ranging from 0 to 25 . Then the scores are transformed to 0-100 by multiplying by 4 , with higher scores meaning better well-being. Cronbach's alpha for the present sample was .78.

Emotion regulation strategies were measured with the Cognitive Emotion Regulation Questionnaire (CERQ) (Garnefski, Kraaij, \& Spinhoven, 2002; Romanian adaptation, Perte \& Tincas, 2010). The CERQ is a self-report questionnaire designed to measure cognitive coping strategies, assessing what people think after confronting specific negative events, or to assess the way people generally react after confronting negative events. The scale is comprised of nine sub scales: self-blame, acceptance, rumination, positive refocusing, refocus on planning, positive reappraisal, putting into perspective, catastrophizing, other blame, each subscale containing four items. Subjects have to indicate on a five-point Likert scale (almost never - to - almost always) the frequency 
with which they use the specific cognitive emotion regulation strategy. The internal consistency of the subscales for the present student population range from .74 to .89 .

Sources of discomfort in the COVID-19 pandemic were measured by an open-ended question, allowing each participant to mention three major sources.

\section{Data analysis}

When analyzing qualitative data, we performed a categorization process depending on specific source of discomfort mentioned by each participant. When analyzing quantitative data, for the univariate analysis, we used absolute and relative frequencies (percentages), while for the correlation analysis we used several correlation coefficients, according to the type of scale variables were measured. For the relationship between categorical variables we used the phi contingency coefficient while for the associations between categorical and interval scales, we used the point biserial coefficient (Cohen, 2001).

\section{RESULTS}

The descriptive characteristics of our sample are presented in Table 1. Most of our participants are females from an urban environment and not married.

Table 1. Descriptive characteristics of the sample

\begin{tabular}{lcc}
\hline Participants characteristics & $\mathrm{n}$ & $\%$ \\
\hline Gender & 39 & \\
Male & 250 & 13.5 \\
Female & & 86.5 \\
Residence & 236 & \\
$\quad$ Urban & & 81.7 \\
\hline
\end{tabular}


ÉVA KÁLLAY, SEBASTIAN PINTEA

\begin{tabular}{lcc}
\hline Participants characteristics & $\mathrm{n}$ & $\%$ \\
\hline Rural & 53 & 18.3 \\
Marital status & & \\
$\quad$ Single & 131 & 45.3 \\
In a relationship & 130 & 45.0 \\
Married & 22 & 7.6 \\
Divorced & 6 & 2.1 \\
\hline Participants characteristics & $\mathrm{M}$ & $\mathrm{SD}$ \\
\hline Age & 24.39 & 7.12 \\
\hline
\end{tabular}

Qualitative data referring to the participants' attitudes, feelings, and thoughts regarding the COVID-19 pandemic and its implications were obtained by asking them to enumerate the most important aspects of the thus-created situation that produces the most discomfort for them. This information was further coded and resulted in the major sources of discomfort as presented in Table 2.

Table 2. Illustrations for each source of discomfort

\begin{tabular}{|c|c|c|}
\hline & $\begin{array}{l}\text { Sources of } \\
\text { discomfort }\end{array}$ & Examples \\
\hline 1 & Restrained mobility & $\begin{array}{l}\text { I cannot go outdoors, I cannot get out, My liberty of } \\
\text { movement is restrained, Traveling restrictions, I am } \\
\text { trapped in one place, Staying at home all day long }\end{array}$ \\
\hline 2 & Health threats & $\begin{array}{l}\text { I am worried about my family health, I am worried } \\
\text { about my health, The risk of getting ill, Fear of not } \\
\text { contracting the virus, I am worried about the health } \\
\text { of mankind }\end{array}$ \\
\hline 3 & Educational problems & $\begin{array}{l}\text { The schools are closed, Uncertainty about the exams, } \\
\text { The online format of teaching and learning, Low con- } \\
\text { centration in online courses, Lack of motivation, Pro- } \\
\text { crastination, I cannot keep up with online learning }\end{array}$ \\
\hline
\end{tabular}


SOCIAL AND PSYCHOLOGICAL CORRELATES OF THE MAJOR SOURCES OF DISCOMFORT PERCEIVED ...

\begin{tabular}{|c|c|c|}
\hline & $\begin{array}{l}\text { Sources of } \\
\text { discomfort }\end{array}$ & Examples \\
\hline 4 & $\begin{array}{l}\text { Restrained social rela- } \\
\text { tions }\end{array}$ & $\begin{array}{l}\text { Lack of socialization, Lack of social relations, I cannot } \\
\text { meet my friends, I miss human interaction, I am not } \\
\text { with my folks, The distance from my beloved ones }\end{array}$ \\
\hline 5 & $\begin{array}{l}\text { Restrained leisure ac- } \\
\text { tivities }\end{array}$ & $\begin{array}{l}\text { Lack of sport activities outdoor, I cannot go out on } \\
\text { holydays, Walking in the mountains, I miss swim- } \\
\text { ming }\end{array}$ \\
\hline 6 & $\begin{array}{l}\text { Problems encoun- } \\
\text { tered in the medical } \\
\text { system }\end{array}$ & $\begin{array}{l}\text { I am worried that the medical system will collapse, } \\
\text { The unprepared health system, The situation of } \\
\text { the hospitals, I am worried about the health sector, } \\
\text { The medical system is not ready, The situation of } \\
\text { medical doctors and nurses }\end{array}$ \\
\hline 7 & Emotional problems & $\begin{array}{l}\text { Feeling of uncertainty, I feel anxious, I feel } \\
\text { stressed by the pandemic, Boredom, Loneliness, } \\
\text { The panic is installing, Hysteria and chaos, Panic, } \\
\text { stress, agitation, General fear, I feel confused, } \\
\text { Fear of death, General panic }\end{array}$ \\
\hline 8 & $\begin{array}{l}\text { Economic implica- } \\
\text { tions }\end{array}$ & $\begin{array}{l}\text { Economic instability, The destruction of economy, } \\
\text { I am worried about my income, Limited stocks of } \\
\text { products, Economic stagnation, Economic crisis, } \\
\text { Lack of money, Unemployment }\end{array}$ \\
\hline 9 & $\begin{array}{l}\text { Increased control } \\
\text { from the authorities }\end{array}$ & $\begin{array}{l}\text { I don't like to fill a form in order to get out, } \\
\text { The control/filters from the police, I don't like that } \\
\text { my body temperature is checked when entering } \\
\text { into a store/institution, Too many rules, } \\
\text { Too much control }\end{array}$ \\
\hline 10 & Mass-media confusion & $\begin{array}{l}\text { The stressful effect of television, The manipulation in } \\
\text { mass-media, The anxiety generated by mass-media, } \\
\text { Too much news about COVID-19 }\end{array}$ \\
\hline 11 & $\begin{array}{l}\text { Population's negative } \\
\text { attitudes }\end{array}$ & $\begin{array}{l}\text { People do not respect the rules, People's lack of re- } \\
\text { sponsibility, People's egoism, insensitiveness, injus- } \\
\text { tice, People's lack of precaution, People's ignorance, } \\
\text { People are always unsatisfied }\end{array}$ \\
\hline
\end{tabular}


In order to ensure consistency and construct validity of coding, the coding criteria were jointly developed by the authors. Next, the coding was performed by both authors. All disagreements were resolved through mutual consensus.

We continued our investigation with establishing the hierarchy for reported sources of discomfort in COVID-19 pandemic. Data were treated as multiple responses. Consequently, the unit of analysis is the response and not necessarily the participant and implicitly, the total number of responses (n) exceeds the number of participants $(\mathrm{N})$.

Table 3. Hierarchy for reported sources of discomfort in COVID-19 pandemic

\begin{tabular}{llcc}
\hline Rank & Source of discomfort & $\mathrm{n}$ & $\%$ \\
\hline 1 & Restrained mobility & 188 & 65.1 \\
\hline 2 & Restrained social relations & 173 & 59.9 \\
\hline 3 & Emotional problems & 143 & 49.5 \\
\hline 4 & Educational problems & 102 & 35.3 \\
\hline 5 & Economic implications & 48 & 16.6 \\
\hline 6 & Health threats & 33 & 11.4 \\
\hline 7 & Population's negative attitudes & 33 & 11.4 \\
\hline 8 & Increased control from the authorities & 31 & 10.7 \\
\hline 9 & Mass-media confusion & 28 & 9.7 \\
\hline 10 & Restrained leisure activities & 23 & 8.0 \\
\hline 11 & Problems encountered in the medical system & 10 & 3.5 \\
\hline
\end{tabular}

Results presented in Table 3 show that the most frequent sources of discomfort reported were restrained mobility (65.1\%), restrained social relations (59.9\%) and subjective/emotional problems (49.5\%), while the less frequently reported were mass-media confusion (9.7\%), restrained leisure activities (8\%), and problems encountered by the medical system (3.5\%).

In the next step, we tested the correlation between the perceived sources of discomfort and the main socio-demographic characteristics of the participants. 
SOCIAL AND PSYCHOLOGICAL CORRELATES OF THE MAJOR SOURCES OF DISCOMFORT PERCEIVED ...

Table 4. Socio-demographic correlates of perceived sources of discomfort

\begin{tabular}{llccc}
\hline Rank & Source of discomfort & $\begin{array}{c}\text { Gender } \\
\text { (0=female, } 1=\text { male, } \\
\text { Contingency } \\
\text { coefficient phi) }\end{array}$ & $\begin{array}{c}\text { Age } \\
\text { (Point-Biserial } \\
\text { correlation } \\
\text { coefficient })\end{array}$ & $\begin{array}{c}\text { Residence } \\
\text { (1= urban, } 0=\text { ru- } \\
\text { ral Contingency } \\
\text { coefficient phi) }\end{array}$ \\
\hline 1 & Restrained mobility & $.120^{*}$ & -.010 & $.140^{*}$ \\
\hline 2 & $\begin{array}{l}\text { Restrained social rela- } \\
\text { tions }\end{array}$ & -.014 & $.148^{*}$ & .001 \\
\hline 3 & Emotional problems & $.111^{\mathrm{a}}$ & $-.243^{* *}$ & $-.174^{* *}$ \\
\hline 4 & Educational problems & .075 & $-.158^{* *}$ & .086 \\
\hline 5 & Economic implications & .034 & -.032 & .040 \\
\hline 6 & Health threats & -.075 & .000 & .090 \\
\hline 7 & $\begin{array}{l}\text { Population's negative } \\
\text { attitudes }\end{array}$ & -.067 & .056 & -.050 \\
\hline 8 & $\begin{array}{l}\text { Increased control from } \\
\text { the authorities }\end{array}$ & -.040 & .043 & -.029 \\
\hline 9 & Mass-media confusion & .092 & .077 & .049 \\
\hline 10 & $\begin{array}{l}\text { Restrained leisure ac- } \\
\text { tivities }\end{array}$ & -.027 & .061 & -.056 \\
\hline 11 & $\begin{array}{l}\text { Problems encountered } \\
\text { by the medical system }\end{array}$ & $-.110 \underline{\mathrm{a}}$ & .037 & .030 \\
\hline
\end{tabular}

Note: ${ }^{a} p<.10,{ }^{*} p<.05,{ }^{* *} p<.01, N=289$

As Table 4 shows, male gender is significantly $(\mathrm{p}<.05)$ or marginally $(\mathrm{p}<.10)$ correlated with restrained mobility and subjective/emotional discomfort (higher probabilities of mentioning these two sources of discomfort compared to female gender). Also, problems encountered in the medical system are more frequently mentioned by women. All the above correlations have rather low intensities. As far as age is concerned, younger participants seem to have higher probabilities of mentioning educational and economic problems, while older participants report more frequently restrained social relations as a source of discomfort. Taking into account also their residence, the results show that urban residents are significantly more affected by restrained mobility but less 
affected by subjective/emotional problems. It is also worth mentioning that all significant correlations had rather low magnitudes.

Further on, we tested the correlation between the perceived sources of discomfort and the emotional regulation strategies used by participants. Results are presented in Table 5.

Table 5. The point-biserial correlations between perceived sources of discomfort and emotional regulation strategies

\begin{tabular}{|c|c|c|c|c|c|c|c|c|c|}
\hline \multirow[b]{2}{*}{$\begin{array}{l}\text { Sources of } \\
\text { discomfort }\end{array}$} & \multicolumn{9}{|c|}{ CERQ } \\
\hline & $\begin{array}{l}\text { Self- } \\
\text { blame }\end{array}$ & $\begin{array}{c}\text { Ac- } \\
\text { ceptance }\end{array}$ & $\begin{array}{l}\text { Rumi- } \\
\text { nation }\end{array}$ & $\begin{array}{l}\text { Posi- } \\
\text { tive re- } \\
\text { focus }\end{array}$ & $\begin{array}{l}\text { Refocus } \\
\text { on plan- } \\
\text { ning }\end{array}$ & $\begin{array}{l}\text { Positive } \\
\text { reevalua- } \\
\text { tion }\end{array}$ & $\begin{array}{l}\text { Putinto } \\
\text { per- } \\
\text { spective }\end{array}$ & $\begin{array}{l}\text { Catastro- } \\
\text { phizing }\end{array}$ & $\begin{array}{l}\text { Others } \\
\text { blame }\end{array}$ \\
\hline $\begin{array}{l}\text { Restrained mo- } \\
\text { bility }\end{array}$ & -.021 & $-.134^{*}$ & -.023 & .005 & -.037 & -.045 & -.026 & .040 & .089 \\
\hline Health threats & $.130^{*}$ & .067 & .079 & -.099 & -.016 & -.078 & -.028 & .102 & -.048 \\
\hline $\begin{array}{l}\text { Educational } \\
\text { problems }\end{array}$ & -.009 & $.130^{*}$ & .075 & -.059 & .064 & .014 & .021 & .008 & -.074 \\
\hline $\begin{array}{l}\text { Restrained so- } \\
\text { cial relations }\end{array}$ & .059 & .019 & .041 & -.074 & -.003 & -.047 & -.014 & .059 & -.021 \\
\hline $\begin{array}{l}\text { Restrained lei- } \\
\text { sure activities }\end{array}$ & .020 & .098 & .031 & .056 & .088 & .095 & .114 & -.048 & -.012 \\
\hline $\begin{array}{l}\text { Medical system } \\
\text { problems }\end{array}$ & -.027 & .037 & .017 & -.027 & .073 & .081 & .049 & .004 & -.049 \\
\hline $\begin{array}{l}\text { Emotional } \\
\text { problems }\end{array}$ & .078 & -.062 & .107 & $-.124^{*}$ & -.114 & $-.154^{* *}$ & $-.133^{*}$ & $.121^{*}$ & .069 \\
\hline $\begin{array}{l}\text { Economic im- } \\
\text { plications }\end{array}$ & .083 & .084 & .000 & -.044 & .022 & .014 & .025 & -.062 & .023 \\
\hline $\begin{array}{l}\text { Increased con- } \\
\text { trol from the } \\
\text { authorities }\end{array}$ & -.095 & -.114 & $-.136^{*}$ & .058 & .016 & .034 & .066 & -.058 & .054 \\
\hline $\begin{array}{l}\text { Mass-media } \\
\text { confusion }\end{array}$ & $-.118^{*}$ & .030 & .006 & $.127^{*}$ & .022 & .109 & $.130^{*}$ & -.073 & .007 \\
\hline $\begin{array}{l}\text { Population's } \\
\text { negative atti- } \\
\text { tudes }\end{array}$ & -.056 & .049 & .006 & $.123^{*}$ & .035 & .055 & .047 & -.027 & -.042 \\
\hline
\end{tabular}

Note: ${ }^{*} p<.05,{ }^{* *} p<.01, N=289$ 
SOCIAL AND PSYCHOLOGICAL CORRELATES OF THE MAJOR SOURCES OF DISCOMFORT PERCEIVED ...

As Table 5 shows, higher levels of self-blame are associated with higher probabilities of reporting health threats as sources of discomfort $\left(r_{p b}=.130\right.$, $\mathrm{p}<.05)$ and lower probabilities of reporting mass-media confusion $\left(r_{p b}=-.118\right.$, $\mathrm{p}<.05)$. Higher acceptance is associated with low probability of mentioning restrained mobility $\left(r_{p b}=-.134, \mathrm{p}<.05\right)$ and higher probability of mentioning educational problems $\left(r_{p b}=.130, \mathrm{p}<.05\right)$. Higher levels of rumination are associated with lower probability of mentioning increased control on the behalf of the authorities $\left(r_{p b}=-.136, \mathrm{p}<.05\right)$. Higher levels of positive refocusing are negatively associated with emotional problems $\left(r_{p b}=-.118, \mathrm{p}<.05\right)$ and positively associated with mentioning mass-media confusion $\left(r_{p b}=.127, \mathrm{p}<.05\right)$ and population's negative attitudes $\left(r_{p b}=.123, \mathrm{p}<.05\right)$. Higher levels of positive reevaluation are negatively associated with lower probability of mentioning emotional problems $\left(r_{p b}=-.154, \mathrm{p}<.05\right)$. Higher levels of putting into perspective are associated with higher probabilities of mentioning mass-media confusion $\left(r_{p b}=.130, \mathrm{p}<.05\right)$ and lower probabilities of mentioning emotional problems $\left(r_{p b}=-.133, \mathrm{p}<.05\right)$, while higher catastrophizing correlates with higher probabilities of mentioning emotional problems $\left(r_{p b}=.121, \mathrm{p}<.05\right)$.

We also tested the correlations between the perceived sources of discomfort generated by COVID-19 pandemic and the personality traits measured. Results are presented in Table 6.

Table 6. The point-biserial correlations between perceived sources of discomfort and personality traits (narcissism, perfectionism, self-esteem)

\begin{tabular}{lccccc}
\hline & \multicolumn{5}{c}{ Personality traits } \\
\cline { 2 - 6 } $\begin{array}{l}\text { Sources of } \\
\text { discomfort }\end{array}$ & $\begin{array}{c}\text { Narcis- } \\
\text { sism }\end{array}$ & pelf-oriented & Others-oriented & Socially-prescribed & Self- \\
perfism & perfectionism & perfectionism & esteem \\
\hline Restrained mobility & $.121^{*}$ & .019 & .019 & -.013 & .095 \\
Health threats & -.050 & -.056 & -.055 & -.045 & .017 \\
$\begin{array}{l}\text { Educational } \\
\text { problems }\end{array}$ & .072 & .016 & .002 & -.099 & -.025 \\
$\begin{array}{l}\text { Restrained social } \\
\text { relations }\end{array}$ & .103 & .017 & .053 & .065 & .023 \\
\hline
\end{tabular}


ÉVA KÁLLAY, SEBASTIAN PINTEA

\begin{tabular}{|c|c|c|c|c|c|}
\hline \multirow[b]{2}{*}{$\begin{array}{l}\text { Sources of } \\
\text { discomfort }\end{array}$} & \multicolumn{5}{|c|}{ Personality traits } \\
\hline & $\begin{array}{c}\text { Narcis- } \\
\text { sism }\end{array}$ & $\begin{array}{c}\text { Self-oriented } \\
\text { perfectionism }\end{array}$ & $\begin{array}{l}\text { Others-oriented } \\
\text { perfectionism }\end{array}$ & $\begin{array}{c}\text { Socially-prescribed } \\
\text { perfectionism }\end{array}$ & $\begin{array}{c}\text { Self- } \\
\text { esteem }\end{array}$ \\
\hline $\begin{array}{l}\text { Restrained } \\
\text { leisure activities }\end{array}$ & .091 & .079 & .030 & .009 & -.099 \\
\hline $\begin{array}{l}\text { Medical system } \\
\text { problems }\end{array}$ & -.076 & .088 & -.015 & -.026 & -.039 \\
\hline $\begin{array}{l}\text { Emotional } \\
\text { problems }\end{array}$ & -.028 & -.060 & -.040 & -.012 & .086 \\
\hline $\begin{array}{l}\text { Economic } \\
\text { implications }\end{array}$ & .004 & .069 & .067 & $.168^{* *}$ & -.005 \\
\hline $\begin{array}{l}\text { Increased control } \\
\text { from the authorities }\end{array}$ & -.005 & -.025 & -.021 & -.027 & -.020 \\
\hline $\begin{array}{l}\text { Mass-media } \\
\text { confusion }\end{array}$ & -.006 & -.011 & .008 & .078 & -.050 \\
\hline $\begin{array}{l}\text { Population's } \\
\text { negative attitudes }\end{array}$ & $-.130^{*}$ & -.061 & -.076 & -.073 & -.050 \\
\hline
\end{tabular}

Note: ${ }^{*} p<.05,{ }^{* *} p<.01, N=289$

Table 7. The point-biserial correlations between perceived sources of discomfort and subjective reactions (perceived stress, depression, anxiety, well-being)

\begin{tabular}{|c|c|c|c|c|c|}
\hline \multirow[b]{2}{*}{ Sources of discomfort } & \multicolumn{5}{|c|}{ Subjective reactions } \\
\hline & $\begin{array}{l}\text { Perceived } \\
\text { stress }\end{array}$ & $\begin{array}{l}\text { Depressive } \\
\text { symptoms }\end{array}$ & $\begin{array}{l}\text { Prospective } \\
\text { anxiety }\end{array}$ & $\begin{array}{l}\text { Inhibitory } \\
\text { anxiety }\end{array}$ & $\begin{array}{l}\text { Well- } \\
\text { being }\end{array}$ \\
\hline Restrained mobility & -.003 & .028 & .047 & -.011 & .029 \\
\hline Health threats & .101 & .050 & .027 & .053 & -.073 \\
\hline Educational problems & .005 & -.086 & -.088 & $-.146^{*}$ & .020 \\
\hline $\begin{array}{l}\text { Restrained social rela- } \\
\text { tions }\end{array}$ & -.032 & -.009 & -.050 & -.052 & .019 \\
\hline $\begin{array}{l}\text { Restrained leisure ac- } \\
\text { tivities }\end{array}$ & -.072 & -.051 & -.033 & -.014 & .044 \\
\hline $\begin{array}{l}\text { Medical system prob- } \\
\text { lems }\end{array}$ & -.080 & -.012 & -.015 & .001 & .041 \\
\hline Emotional problems & $.201^{* *}$ & $.189^{* *}$ & $.151^{*}$ & $.173^{* *}$ & $-.219^{* *}$ \\
\hline
\end{tabular}


SOCIAL AND PSYCHOLOGICAL CORRELATES OF THE MAJOR SOURCES OF DISCOMFORT PERCEIVED ...

\begin{tabular}{|c|c|c|c|c|c|}
\hline \multirow[b]{2}{*}{ Sources of discomfort } & \multicolumn{5}{|c|}{ Subjective reactions } \\
\hline & $\begin{array}{l}\text { Perceived } \\
\text { stress }\end{array}$ & $\begin{array}{l}\text { Depressive } \\
\text { symptoms }\end{array}$ & $\begin{array}{l}\text { Prospective } \\
\text { anxiety }\end{array}$ & $\begin{array}{l}\text { Inhibitory } \\
\text { anxiety }\end{array}$ & $\begin{array}{l}\text { Well- } \\
\text { being }\end{array}$ \\
\hline Economic implications & .072 & .067 & .007 & .036 & -.090 \\
\hline $\begin{array}{l}\text { Increased control from } \\
\text { the authorities }\end{array}$ & -.027 & -.002 & .072 & .086 & -.040 \\
\hline Mass-media confusion & $-.136^{*}$ & -.044 & -.022 & -.022 & .115 \\
\hline $\begin{array}{l}\text { Population's negative } \\
\text { attitudes }\end{array}$ & -.053 & -.047 & -.027 & .039 & -.017 \\
\hline
\end{tabular}

Note: ${ }^{*} p<.05, * * p<.01, N=289$

According to Table 7, mentioning emotional problems, was significantly associated with higher levels of perceived stress $\left(r_{p b}=.201, \mathrm{p}<.01\right)$, higher depressive symptoms $\left(r_{p b}=.189, \mathrm{p}<.01\right)$, higher prospective and inhibitory anxiety $\left(r_{p b}=.151, \mathrm{p}<.05\right.$ and $\left.r_{p b}=.173, \mathrm{p}<.01\right)$ and with lower levels of well-being $\left(r_{p b}=-\right.$ $.219, \mathrm{p}<.05)$. Meanwhile, mentioning educational problems was associated with lower inhibitory anxiety $\left(r_{p b}=-.146, \mathrm{p}<.05\right)$ and mass-media confusion was associated with lower perceived stress $\left(r_{p b}=-.136, \mathrm{p}<.05\right)$.

\section{Conclusions and discussions}

The COVID-19 pandemic generated health-threat, large number of casualties, uncertainty, social isolation, cessation of several professional activities, and the produced economic problems (at the personal and social level), led worldwide to significant, escalating psychological problems, which quickly became an extremely serious public mental health problem (Phelan, Katz, \& Gostin, 2020; Vergara-Buenaventura, Chavez-Tuñon, \& Castro-Ruiz, 2020; WHO, 2020). Research indicates that in such situations is crucial to identify the associated dysfunctional psychological reactions and the vulnerabilities of the population, in order to assist authorities and health care services to intervene in their amelioration with well targeted strategies (Taylor, 2019). The COVID-19 generated also a plethora of research investigating the effects of the pandemic on different populations. Nevertheless, the number of studies investigating the 
impact of the present pandemic on the psychological functioning of university students is extremely scarce, although this is a particularly vulnerable population to mental health problems especially if we take into consideration the fact that they have to face the transition from adolescence to adulthood (Husky, Kovess-Masfety, \& Swendsen, 2020). In students, emotional and mental well-being are strongly related to their academic achievements (Esch, Bocquet, Pull, Couffignal, Lehnert, Graas, Fond-Harmant, \& Ansseau, 2014; Fletcher, 2010), affecting motivation, implication, concentration, social relationships, etc. (Unger, 2007). Students may also be seriously affected not only by the inherent lifethreatening aspects of the situations, but also by the resulting social restrictions which may seriously block face-to-face socialization and consolidation of the subjacent abilities (Fegert \& Schulze, 2020). Thus, it became extremely important to investigate the specificities of psychological reactions caused by the COVID-19 pandemic in student populations (Cao, Fang, Hou, Han, Xu, Dong, \& Zheng, 2020).

Consequently, our research intended to investigate the relationship between intrapersonal protective and risk factors as cognitive emotion-regulation strategies, self-esteem, narcissism, perfectionism, and reactions to adversity, as perceived stress, depressive symptomatology, intolerance of uncertainty, and subjective well-being. Our study had three major objectives: (1) to identify the major sources of discomfort in third year psychology students; (2) to establish a hierarchy of the most important sources of discomfort, and (3) to identify possible vulnerabilities for different sources of discomfort.

Next, we will discuss the implications of our results separately, based upon each category of factors taken into account.

Gender differences. Our results show several gender differences. First, men report mobility restrictions as a source of discomfort more frequently than female participants. One explanation of this difference may be attributable to the gender differences regarding the perceived seriousness of COVID-19 as a health problem, revealed by Galasso et al. (2020), and also regarding the agreement and compliance with the governmental restrictions. Analyzing data from eight countries, the authors found that men perceived COVID-19 as less of a threat compared to women and also proved less agreement with the overall restrictions. Consequently, if COVID-19 is less of a threat for men, the mobility 
restrictions imposed by the government are less justified for them and a source of discomfort of higher importance. Also, other studies found that women are generally more favorable to government interventions (Edlund \& Pande, 2002; Ingelhart \& Norris, 2000) and more risk averse than men (Crosson \& Gneezy, 2009) which could also explain why women are less subjectively affected by mobility restrictions. Also, we found that women are more concerned with the problems encountered in the medical system, which could be explained by the fact that women are more likely socialized to become caregivers (Gallaso et al., 2020) and more sensitive to the quality of caregiving services.

Age differences. As far as age is concerned, our results show that younger students are less concerned with restrictions regarding social relations, while older students report less emotional problems and less concern with educational problems. The first result is in line with studies such as Vega et al. (2020) who found on a Spanish sample that younger participants were less affected by preventive measures and towards the need of staying home than adults and older adults. An explanation for this result could be the fact that younger people are more familiar with communication technologies and consequently are compensating the physical distance with more intense social interaction in the virtual environment. As far as the second result is concerned, its direction is in line with other studies showing that older people had more optimistic outlook and better mental health, at least during the early stages of the pandemic (Bruin, 2021). Other studies also found that younger adults had lower perceived coping efficacy with COVID-19 stressors than older adults, and also lower positive affect and higher negative affect (Klaiber et al., 2021). Older students could also report less emotional discomfort because they are more likely to have stable relationships and implicitly more social support which generate more emotional equilibrium. Regarding the third result, older students might report less concern with educational problems because most of them are already working, so their jobs are not necessarily affected by the educational program they are currently following. Also, most of the older students already have a first bachelor degree and they are currently studying to get the second one, and consequently, they are not largely affected by the interference of pandemic restrictions with the educational process. 
Residence. Our results show that students living in urban areas report less emotional problems than students from rural areas but they are more affected by mobility restrictions. As far as emotional problems are concerned, the differences could be explained by differences in functional coping strategies, with advantages for urban residents (Shannon et al., 2006). As far as mobility restrictions are concerned, previous studies that compared COVID-19 attitudes and behaviors between rural and urban residents from China, indicated that rural residents were less likely to perform preventive behaviors, more likely to hold a negative attitude toward the effectiveness of performing preventive behaviors, and more likely to have lower levels of information appraisal skills (Chen \& Chen, 2020) and also had a lower level of health literacy (Yue et al., 2020).Also, surveys on American population show that residents from rural areas believed to a higher degree that the threat of COVID-19 had been blown out of proportion, that the coronavirus is less of a threat to public and personal health and proved less concern about hospital resources (Boyle \& Dayton, 2020). Even if in our study we have both rural and urban residents, the particularity of our sample is that both categories include only students. In other words, for this particular case, with higher educated participants, the fact that urban residents are more affected by mobility restrictions could be explained by the fact that cities offer a larger set of opportunities for entertainment and loisir, so the frustrations generated by mobility restrictions are higher than in rural areas. Also another explanation could be the fact that in urban areas, at least in Romania, the large majority of people are living in small building-block apartments and severe mobility restrictions left them with very few options of moving and exercise. On the other hand, for rural residents, living in houses with backyards and having daily homesteading activities, mobility restrictions had a lower impact.

Emotion regulation strategies. Literature indicates that emotion regulation strategies are strongly related to different aspects of mental health, especially depression and anxiety (Aldao et al., 2010; Aldao \& Dixon-Gordon, 2014; Garnefski \& Kraaij, 2006, 2007; Gross \& Jazaieri, 2014; Liu \& Thompson, 2017). More specifically, the habitual use of emotion regulation strategies as planning and positive reappraisal favor adaptation, while the frequent use of strategies 
as such catastrophizing, other blame, self-blame and rumination malfunctioning in face of adversity (Balzarotti, Biassoni, Villani, Prunas, \& Velotti, 2016; Garnefski \& Kraaij 2007; Legerstee et al., 2011). Thus, the use of adaptive emotion regulation strategies becomes crucial in critical life conditions as COVID-19 pandemics (Restubog, Ocampo, \& Wang,2020).

Our results indicate that those participants who reported higher levels of self-blame feel that their physical health is more threatened than those who use significantly less this emotion regulations strategy. This result is consistent with the findings in the literature, which indicate that attributional styles specific to self-blame predispose individuals to more emotional ill-health (e.g., depression) (Anderson, Miller, Riger, Dill, \& Sedikides, 1994). They consider that they are responsible for what most of the things that happen to them, and oftentimes overestimate their role in the way things resolve in time. Consequently, it is not surprising that those participants in our study who habitually use self-blame also experience less confusion induced by mass-media. This may be due to the fact, that due to their specific attributional style these individuals attribute more importance to their role in the unfolding of events than to information coming from other agents (in this case mass media).

Our results also indicate that those who report higher levels of acceptance are less affected by restrained mobility, but more affected by educational problems. The first part of this result is in line with previous findings which show that one's capacity to accept and become reconciled with the implications of a negative situation present higher levels of optimism and self-esteem, and lower levels of anxiety (Garnefski, Kraaij, \& Spinhoven, 2001). The higher level of distress regarding educational problems may be due to the fact that in situations in which the person considers that he/she should have more control (in this case the educational trajectory), acceptance may attain a passive connotation which may negatively impact one's adaptive processes. In this situation, we consider to emphasize that literature frequently considers specific emotion regulation strategies as being adaptive or maladaptive without considering their adaptive value reported to the specificity of the context. Sometimes, a situation is extremely complex, requiring a more nuanced use of a blend of different emotion regulation strategies. Thus, it is more productive to immerse 
the interpretation regarding the adaptiveness of these results after considering their role in the specific situation than a priory considering a strategy as being adaptive or maladaptive without investigating the requirements of the environment (Aldao, 2013). Regarding rumination, our results also reflect those who ruminate more are less affected by the control exerted by the authorities. Even if literature a priory considers that rumination is maladaptive, research also indicates that when rumination may also include self-reflective components, which in certain situations may confer to it an adaptive role (Nolen-Hoeksema, Wisco, \& Lyubomirsky, 2008).

Next, our results indicated that those who habitually use positive refocusing are less affected by emotional problems. These results are similar to those of previous studies, which indicate that the capacity to mentally disengage from one aspect of a negative problem and refocus on a positive aspect of it is adaptive and in the short run reduces negative affectivity (Endler \& Parker, 1990). However, this emotion-regulation strategy used for a prolonged period of time may impede efficient adaptation (Garnefski et al., 2001), conclusion that is also reflected by our results in which these individuals are more affected by the confusion created by mass-media regarding the unfolding of the Pandemics, its implications, etc., as well as by the opinion of other people. In line with previous results are our findings in which those who habitually use positive reappraisal are less negatively affected by the negative events in the pandemics (Garnefski et al., 2001; Garnefski, Teerds, Kraaij, Legerstee, \& van den Kommer, 2004). The same holds to our findings in which those who use the strategy of putting into perspective are less affected emotionally (Garnefski et al., 2001). This was expectable, since putting into perspective the individual minimizes the implications of the event by comparing it to the implications of other, apparently more important events (Allan \& Gilbert, 1995). Finally, those participants who habitually used catastrophizing were also more affected emotionally reflects the numerous similar findings in the literature (Garnefski et al., 2004; Nolan-Hoeksema et al., 2008; Sullivan, Bishop, \& Pivik, 1995).

Personality characteristics - narcissism and perfectionism. With regard to personality characteristics our results indicate that that those participants who report higher levels of narcissistic traits are more affected by restrained 
mobility and less affected by the negative attitude of the population. Recent research indicates that even during Pandemics, individuals with narcissistic traits were found to refuse to comply more frequently to the rules imposed (Nowak, Brzóska, Piotrowski, Sedikides, Żemojtel-Piotrowska, \& Jonason, 2020; Zajenkowski, Jonason Leniarska, \& Kozakiewicz, 2020). These findings are probably associated with both the narcissistic persons' self-centeredness, entitlement, need for admiration and approval (Urbonaviciute, \& Hepper, 2020). When these needs are not met by their environment, narcissists may be emotionally affected (e.g., depressive symptomatology, anger, emotional discomfort). In the same time, since narcissistic individuals are characterized by reduced levels of empathy (Campbell \& Foster, 2007; Hepper, Hart, \& Sedikides, 2014; Kernberg, 1985), it is not surprising that they are not affected by the attitude of others, be those negative of positive. This result may also be interpreted in the light of their reticence to abide to authorities (Nowak et al., 2020; Zajenowski et al., 2020).

Our research also indicated that those participants who attained higher levels of socially prescribed perfectionism are more affected by economic problems. This result may be traced back to their characteristics that these individuals have a constant need to obtain others' approval, thus they have to constantly display a perfect image of themselves (Curran \& Hill, 2017). A plethora of research indicates that perfectionism is a basic component of narcissism, and both may be strongly related to consumerist and materialistic values, strong orientation towards financial issues (Beck, Freeman, \& Davis, 2004; Rothstein, 1999; Twenge, 2013; 2014).

Subjective emotional reactions. Regarding subjective reactions, those participants who reported higher levels of distress also reported significantly higher emotional problems, which obviously is explicable by the overlap between similar concepts (distress and different emotional problems, positive and negative) (Eysenck \& Fajkowska, 2017; Goodwin, 2015). Less is explicable for why those who reported higher levels of distress report less confusion produced by the mass-media. It is possible that those who are more distressed pay less attention to the flux of information, or their attention is driven to other aspects of the situation (e.g., concentration on the problems in their proximity). This aspect has to be investigated by future studies. 
Inhibitory anxiety, one of the major component of intolerance of uncertainty refers to the distress caused by the uncertainty that impedes action or experience. Thus, our results that indicate a strong relationship between inhibitory anxiety and emotional problems may be due to the fact that restrained action and experience may induce negative affectivity by reducing the individual's chance to obtain interaction and positive feedback from others (Coyne, 1989). Finally, in our study subjective well-being is negatively associated with emotional problems, finding that reflects trends in the literature (Lee, 2020; Winefield, Gill, Taylor, \& Pilkington, 2012).

\section{Limitations}

Beyond the findings explained here, our study has also several limitations for which the authors take full responsibility. First, our study is cross-sectional and does not bring direct evidence to prove that the concepts named here as vulnerabilities for certain sources of discomfort are actually antecedents of such subjective evaluations. Second, we are aware that our study includes a large number of variables which means a possible escalation for the probability of false positive results. We tried to compensate this disadvantage by focusing the analyses not just upon statistical significance, but also upon effect sizes. Another methodological limit is that when measuring sources of discomfort, we allowed for brevity's sake each participant to mention only three major sources. We are aware that without such a constraint, the frequency of each source and implicitly their hierarchy could have been different from the one found in our analysis.

\section{Future direction for research}

Based upon the experience of this study we recommend for future studies to transform the sources of discomfort identified here in items with close options of response, and including them in more complex predictive models which could bring evidence also for the chronological order of the vulnerabilities, through multiple mediation models. 
SOCIAL AND PSYCHOLOGICAL CORRELATES OF THE MAJOR SOURCES OF DISCOMFORT PERCEIVED ...

Finally, we consider that the results generated by our research that point out certain social and psychological vulnerabilities for each perceived source of discomfort, can bring a valuable input in counseling and therapy for individuals who are maximally affected by the pandemic ofCOVID-19 and ultimately smoothing the transition toward normality.

\section{REFERENCES}

Aldao, A. (2013). The future of emotion regulation research: Capturing Context. Perspectives on Psychological Science. 8(2), 155-172. doi: $10.1177 / 1745691612459518$

Aldao, A., \& Dixon-Gordon, K. L. (2014). Broadening the scope of research on emotion regulation strategies and psychopathology. Cognitive Behavior Therapy, 43, 2233. doi: 10.1080/16506073.2013.816769

Aldao, A., Nolen-Hoeksema, S., \& Schweizer, S. (2010). Emotion-regulation strategies across psychopathology: A meta-analytic review. Clinical Psychological Review, 30, 217-237. doi: 10.1016/j.cpr.2009.11.004

Allan, S., \& Gilbert, P. (1995). A social comparison scale: psychometric properties and relationship to psychopathology. Journal of Personality and Individual Differences, 19, 293-299.

Anderson, C. A., Miller, R. S., Riger, A. L., Dill, J. C., \& Sedikides, C. (1994). Behavioral and characterological styles as predictors of depression and loneliness: Review, refinement, and test. Journal of Personality and Social Psychology, 66, 549-558.

Anwar, A., Malik, M., Raees, V., \& Anwar, A. (2020). Role of mass media and public health communications in the COVID-19 Pandemic. Cureus, 12(9), e10453. doi:10.7759/cureus.10453

American Psychiatric Association. (2013). Diagnostic and statistical manual of mental disorders ( $5^{\text {th }}$ Ed.). Washington, DC: Author.

Auerbach, R. P., Mortier, P., Bruffaerts, R., Alonso, J., Benjet, C., Cuijpers, P., Demyttenaere, K., Ebert, D. D., Green, J. G., Hasking, P., Murray, E., Nock, M. K., PinderAmaker, S., Sampson, N. A., Stein, D. J., Vilagut, G., Zaslavsky, A. M., Kessler, R. C., \& WHO WMH-ICS Collaborators. (2018). WHO World Mental Health Surveys International College Student Project: Prevalence and distribution of mental disorders. Journal of Abnormal Psychology, 127(7), 623-638.

doi:10.1037/abn0000362 


\section{ÉVA KÁLLAY, SEBASTIAN PINTEA}

Balzarotti, S., Biassoni, F., Villani, D., Prunas, A., \& Velotti, P. (2016). Individual differences in cognitive emotion regulation: Implications for subjective and psychological well-being. Journal of Happiness Studies: An Interdisciplinary Forum on Subjective Well-Being, 17(1), 125- 143. doi:10.1007/s10902-014-9587-3

Bao, Y., Sun, Y., Meng, S., Shi, J., \& Lu, L. (2020). 2019-nCoV epidemic: Address mental health care to empower society. Lancet, 395(10224), e37-e8.

Blanco, C., Okuda, M., Wright, C., Hasin, D. S., Grant, B. F., Liu, S. M., \& Olfson, M. (2008). Mental health of college students and their non-college-attending peers: Results from the National Epidemiologic Study on Alcohol and Related Conditions. Archives of General Psychiatry. 65(12), 1429-37. doi: 10.1001/archpsyc.65.12.1429

Boyle, J., \& Dayton, J. (2020). Rural Americans feel less threatened by COVID-19 than urban and suburban Americans do, but still view mitigation as important. Inner City Fund. Article retrieved at https://www.icf.com/insights/health/covid-19survey-rural-vs-urban-threat

Bradlee, P. M., \& Emmons, R. A. (1992). Locating narcissism within the interpersonal circumplex and the five-factor model. Personality and Individual Differences, 13, 821-830.

Brooks, S. K., Webster, R. K., Smith, L. E., Woodland, L., Wessely, S., Greenberg, N., \& Rubin, G. J. (2020). The psychological impact of quarantine and how to reduce it: Rapid review of the evidence. Lancet,14, 395(10227), 912-920.

Bruin, W.B. (2021). Age differences in COVID-19 risk perceptions and mental health: Evidence from a National U.S. Survey conducted in March 2020. The Journals of Gerontology,76(2), e24-e29. doi:10.1093/geronb/gbaa074

Campbell, W. K., \& Foster, J. D. (2007). The narcissistic self: Background, an extended agency model, and ongoing controversies. In C. Sedikides \& S. J. Spencer (Eds.). Frontiers in social psychology: The Self (pp. 115-138). Philadelphia, PA: Psychology Press. doi:10.4324/9780203818572

Cao, W., Fang, Z., Hou, G., Han, M., Xu, X., Dong, J., \& Zheng, J. (2020). The psychological impact of the COVID-19 epidemic on college students in China. Psychiatry Research, 287, 112934. doi:10.1016/j.psychres.2020.112934

Carleton, R. N., Norton, P. J., \& Asmundson, G. J. G. (2007). Fearing the unknown: A short version of the Intolerance of Uncertainty Scale. Journal of Anxiety Disorders, 21, 105-117.

Carver, C. S., Scheier, M. F., \& Weintraub, J. K. (1989). Assessing coping strategies: a theoretically based approach. Journal of Personality and Social Psychology, 56, 267283. 
SOCIAL AND PSYCHOLOGICAL CORRELATES OF THE MAJOR SOURCES OF DISCOMFORT PERCEIVED ...

Chen, X., \& Chen, H. (2020). Differences in preventive behaviors of COVID-19 between urban and rural residents: Lessons learned from a cross-sectional study in China. International Journal of Environmental Research and Public Health, 17(12), 4437. doi:10.3390/ijerph17124437

Cohen, B. H. (2001). Explaining Psychological Statistics (Second Ed.) New York: Wiley.

Cohen, S., Kamarck, T., \& Mermelstein, R. (1983). A global measure of perceived stress. Journal of Health and Social Behavior, 24(4), 385-396. doi: $10.2307 / 2136404$

Coyne, J. C. (1989). Thinking post-cognitively about depression. In A. Freeman, K. M. Simon, L. E. Butler, \& H. Arkowitz (Eds.), Comprehensive handbook of cognitive therapy (pp. 227-244). New York: Plenum Press.

Croson, R., \& Gneezy, U. (2009). Gender differences in preferences. Journal of Economic Literature, 47(2), 448-474.

Dickinson, K., A., \& Pincus, A. L. (2003). Interpersonal analysis of grandiose and vulnerable narcissism. Journal of Personality Disorders, 17(3), 188-207.

Edlund, L., \& Pande, R. (2002). Why have women become left-wing? The political gender gap and the decline in marriage. The Quarterly Journal of Economics, 117(3), 917-961.

Endler, N. S., \& Parker, J. D. A. (1990). Multidimensional assessment of coping: A critical evaluation. Journal of Personality and Social Psychology, 58, 844-854.

Esch, P., Bocquet, V., Pull, C., Couffignal, S., Lehnert, T., Graas, M., et al. (2014). The downward spiral of mental disorders and educational attainment: A systematic review on early school leaving. BMC Psychiatry 14, 237

https://doi.org/10.1186/s12888-014-0237-4

Eurostat (2020). Impact of Covid-19 crisis on short-term statistics.

Retrieved 2020 January $4^{\text {th }}$.

https://ec.europa.eu/eurostat/statistics-explained/index.php?title=

Impact_of_Covid-19_crisis_on_short-term_statistics

Eysenck, M. W., \& Fajkowska, M. (2018). Anxiety and depression: toward overlapping and distinctive features. Cognition and Emotion, 32(7), 1391-1400. doi: 10.1080/02699931.2017.1330255

Fegert, J. M., \& Schulze, U. M. E. (2020). COVID-19 and its impact on child and adolescent psychiatry - a German and personal perspective. Irish Journal of Psychological Medicine, 37, 243-245. doi: 10.1017/ipm.2020.43. 
ÉVA KÁLLAY, SEBASTIAN PINTEA

Fernández-Abascal, E. G., \& Martín-Díaz, M. D. (2021). Longitudinal study on affect, psychological well-being, depression, mental and physical health, prior to and during the COVID-19 pandemic in Spain. Personality and Individual Differences, 17. doi:110591.10.1016/j.paid.2020.110591

Fletcher, J. M. (2010). Adolescent depression and educational attainment: Results using sibling fixed effects. Health Economy, 19, 855-871.

Flett, G. L., \& Hewitt, P. L. (2002). Perfectionism and maladjustment: An overview of theoretical, definitional, and treatment issues. In P. L. Hewitt \& G. L. Flett (Eds.), Perfectionism (pp. 5-31). Washington, DC: APA.

Friedlander, L. J., Reid, G. J., Shupak, N., \& Cribbie, R. (2007). Social support, self-esteem, and stress as predictors of adjustment to university among first-year undergraduates. Journal of College Student Development, 48(3), 259-274.

doi:10.1353/csd.2007.0024

Fry, P. S., \& Debats, D. L. (2009). Perfectionism and the five-factor personality traits as predictors of mortality in older adults. Journal of Health Psychology, 14, 513524. doi: 10.1177/1359105309103571

Gao, J., Zheng, P., Jia, Y., Chen, H., Mao, Y., Chen, S., et al. (2020) Mental health problems and social media exposure during COVID-19 outbreak. PLOS ONE, 15(4), e0231924. doi:10.1371/journal.pone.0231924

Galasso, V., Pons, V. Profeta, P., Becher, M., Brouard, S., \& Foucault M. (2020). Gender differences in COVID-19 attitudes and behavior: Panel evidence from eight countries. Proceedings of the National Academy of Sciences, 117(44). 2728527291.

Garnefski, N., \& Kraaij, V. (2006). Relationships between cognitive emotion regulation strategies and depressive symptoms: a comparative study of five specific samples. Personality and Individual Differences, 40, 1659-1669. doi: 10.1016/j.paid.2005.12.

Garnefski, N., \& Kraaij, V. (2007). The cognitive emotion regulation questionnaire: psychometric features and prospective relationships with depression and anxiety in adults. European Journal of Psychological Assessment, 23, 141-149. doi:10.1027/1015-5759.23.3.141

Garnefski, N., Kraaij, V., \& Spinhiven, P. (2001). Negative life events, cognitive emotion regulation and emotional problems. Personality and Individual Differences, 30, 1311-1327. 
SOCIAL AND PSYCHOLOGICAL CORRELATES OF THE MAJOR SOURCES OF DISCOMFORT PERCEIVED ...

Garnefski, N., Kraaij, V., \& Spinhoven, P. (2002). Manual for the use of the Cognitive Emotion Regulation Questionnaire. A questionnaire measuring cognitive coping strategies. Leiderdorp: DATEC

Garnefski, N., Teerds, J., Kraaij, V., Legerstee, J., \& van den Kommer, T. (2004). Cognitive emotion regulation strategies and depressive symptoms: Differences between males and females. Personality and Individual Differences, 36,267-276. doi:10.1016/S0191-8869(03)00083-7

Garnefski, N., van den Kommer, T, Kraaij V., Teerds, J., Legerstee, J., \& Onstein, E. (2001). The relationship between cognitive emotion regulation strategies and emotional problems: Comparison between a clinical and a non-clinical sample. European Journal of Personality, 16, 403-420.

González-Sanguino, C., Ausín, B.,Castellanos, M. Á., Saiz, J., López-Gómez, A., Ugidos, C., \& Muñoz, M. (2020). Mental health consequences of the Coronavirus 2020 Pandemic (COVID-19) in Spain. A Longitudinal Study. Frontiers in Psychiatry, 11, 565474. doi: 10.3389/fpsyt.2020.565474.

Goodwin G. M. (2015). The overlap between anxiety, depression, and obsessive-compulsive disorder. Dialogues in Clinical Neuroscience, 17(3), 249-260.

https://doi.org/10.31887/DCNS.2015.17.3/ggoodwin

Gross, J. J., \& Jazaieri, H. (2014). Emotion, emotion regulation, and psychopathology: an affective science perspective. Clinical Psychology Science, 2, 387-401.doi: $10.1177 / 2167702614536164$

Hepper, E. G., Hart, C. M., Sedikidesm C. (2014). Moving narcissus: Can narcissists be empathic? Personality and Social Psychology Bulletin, 40(9), 1079-1091. doi:10.1177/0146167214535812

Hewitt, P. L., Flett, G. L., \& Mikail, S. F. (2017). Perfectionism: A relational approach to conceptualization, assessment, and treatment. New York, NY: Guilford Press.

Huang, w.-L., Chen, T.-T., Chen, I. M., Chang, L.-R, Lin, Y.-H., Liao, S.-c., \& Gau, S. S.-F. (2016). Harm avoidance and persistence are associated with somatoform disorder psychopathology: A study in Taiwan. Journal of Affective Disorders, 196, 83-86. doi:10.1016/j.jad.2016.02.009

Husky, M. M., Kovess-Masfety, V., \& Swendsen, J. D. (2020). Stress and anxiety among university students in France during Covid-19 mandatory confinement. Comprehensive Psychiatry, 102, 152191.

doi:10.1016/j.comppsych.2020.152191

ILO (2020), "COVID-19 and food retail”, ILO Sectoral Briefs, https://www.ilo.org/wcmsp5/groups/public/---ed_dialogue/---sector/ documents/briefingnote/wcms_741342.pdf 


\section{ÉVA KÁLLAY, SEBASTIAN PINTEA}

Inglehart, R., \& Norris, P. (2000). The developmental theory of the gender gap: women's and men's voting behavior in global perspective. International Political Science Review, 21(4), 441-463.

Kasser, T., \& Ryan, R. M. (1996). Further examining the American dream: Differential correlates of intrinsic and extrinsic goals. Personality and Social Psychology Bulletin, 22, 280-297.

Kernberg, O. F. (1985). Borderline conditions and pathological narcissism. New York: Rowman \& Littlefield.

Klaiber, P., Wen, J. H., DeLongis, A., \& Sin, N. L. (2021). The ups and downs of daily life during COVID-19: Age differences in affect, stress, and positive events. The Journals of Gerontology,76(2), e30-e37. doi:10.1093/geronb/gbaa096

Lauriola, M., Mosca, 0., Trentini, C., Foschi, R., Tambelli, R., \& Carleton, R. N. (2018). The Intolerance and Uncertainty Inventory: Validity and comparison of scoring methods to assess individuals screening positive for anxiety and depression. Frontiers in Psychology, 9, 388. doi.org/310.3389/fpsyg.2018.00388

Lee, S. (2020). Subjective well-being and mental health during the pandemic outbreak: Exploring the role of institutional trust. Research on Aging, 1-12. doi: $10.1177 / 0164027520975145$

Legerstee, J. S., Garnefski, N., Verhulst, F. C., \& Utens, E. M. W. J. (2011). Cognitive coping in anxiety-disordered adolescents. Journal of Adolescence, 34, 319-326. doi: 10.1016/j.adolescence.2010.04.008

Liu, D. Y., \& Thompson, R. J. (2017). Selection and implementation of emotion regulation strategies in major depressive disorder: An integrative review. Clinical Psychology Review, 57, 183-194. doi: 10.1016/j.cpr.2017.07.004

Liu, J., Zhu, Q., Fan, W., Makamure, J., Zheng, C., \& Wang, J. (2020). Online mental health survey in a medical college in China during the COVID-19 outbreak. Frontiers in Psychiatry, 11, 459. doi: 10.3389/fpsyt.2020.00459

Mercier, G., Arquizan, C., \& Roubille, F. (2020). Understanding the effects of COVID-19 on health care and systems. The Lancet, 5, e536. doi:10.1016/S2468-2667(20)30213-9

Mooney, S. P., Sherman, M. F., \& Lo Presto, C. T. (1991). Academic locus of control, selfesteem, and perceived distance from home as predictors of college adjustment. Journal of Counseling \& Development, 69, 445-448.

Nolen-Hoeksema, S, Wisco, B. E., \& Lyubomirsky, S. (2008). Rethinking rumination. Perspectives in Psychological Science, 3(5), 400-24. doi: 10.1111/j.1745-6924.2008.00088.x. PMID: 26158958 
SOCIAL AND PSYCHOLOGICAL CORRELATES OF THE MAJOR SOURCES OF DISCOMFORT PERCEIVED ...

Nolen-Hoeksema, S., Parker, L. E., \& Larson, J. (1994). Ruminative coping with depressed mood following loss. Journal of Personality and Social Psychology, 67, 92-104.

Nowak, B., Brzóska, P., Piotrowski, J., Sedikides, C., Żemojtel-Piotrowska, M., \& Jonason, P. K. (2020). Adaptive and maladaptive behavior during the COVID-19 pandemic: The roles of Dark Triad traits, collective narcissism, and health beliefs. Personality and Individual Differences, 167, 110232.

doi:10.1016/j.paid.2020.110232

O'Bryan, E. M., \& McLeish, A. C. (2017). An examination of the indirect effect of intolerance of uncertainty on health anxiety through anxiety sensitivity physical concerns. Journal of Psychopathology and Behavioral Assessment, 39, 715-722. doi:10.1007/s10862-017-9613-y

OECD (2020a). COVID-19 and the food and agriculture sector: Issues and policy responses. OECD, Paris, https://read.oecd-ilibrary.org/view/?ref=130_130816-9uut45lj4q\&title= Covid-19-and-the-food-and-agriculture-sector-Issues-and-policy-responses

OECD (2020b). Corporate sector vulnerabilities during the Covid-19 outbreak: Assessment and policy responses". OECD, Paris, www.oecd.org/coronavirus/policy-responses/corporate-sector-vulnerabilities-during-the-covid-19-outbreak-a6e670ea/.

Pappa, S., Ntella, V., Giannakas, T., Giannakoulis, V. G., Papoutsi, E., \& Katsaounou, P. (2020). Prevalence of depression, anxiety, and insomnia among healthcare workers during the COVID-19 pandemic: A systematic review and meta-analysis. Brain Behavior, and Immunity, 88, 901-7. doi: 10.1016/j.bbi.2020.05.026

Panzeri, M., Ferrucci, R., Cozza, A., \& Fontanesi, L. (2020). Changes in sexuality and quality of couple relationship during the COVID-19 lockdown. Frontiers in Psychology, 11, 565823. https://doi.org/10.3389/fpsyg.2020.565823

Perte, A., \& Tincas, I. (2010). CERQ - Manualul de utilizare a Chestionarului de coping cognitiv - emotional. Adaptarea si standardizarea CERQ pe populatia din România. Cluj-Napoca: ASCR Press.

Peteet, J. R. (2020). COVID-19 anxiety. Journal of Religious Health, 59(5), 2203-2204. doi: 10.1007/s10943-020-01041-4

Phelan, A. L., Katz, R., \& Gostin, L. O. (2020). The novel coronavirus originating in Wuhan, China: Challenges for global health governance. JAMA.

doi: 10.1001/jama.2020.1097. 


\section{ÉVA KÁLLAY, SEBASTIAN PINTEA}

Restubog, S., Ocampo, A., \& Wang, L. (2020). Taking control amidst the chaos: emotion regulation during the COVID-19 pandemic. Journal of Vocational Behavior, 119,103440. doi: 10.1016/j.jvb.2020.103440

Rosenberg, M. (1979). Conceiving the Self. New York: Basic Books.

Rosser, B. A (2018). Intolerance of uncertainty as a trans-diagnostic mechanism of psychological difficulties: A systematic review of evidence pertaining to causality and temporal precedence. Cognitive Therapy and Research. doi:10.1007/s10608-018-9964-z

Shannon, L., Logan, T., Cole, J., \& Medley, K. (2006). Help-seeking and coping strategies for intimate partner violence in rural and urban women. Violence and Victims, 21(2), 167-181. doi:10.1891/vivi.21.2.167

Shepperd, J. A, Waters, E. A, Weinstein, N. D., \& Klein, W M. P. (2015). A primer on unrealistic optimism. Current Directions in Psychological Science, 24, 232-237. doi:10.1177/0963721414568341

Sherry, S. B., Gralnick, T. M., Hewitt, P. L., Sherry, D, L., \&Flett, G. L. (2014). Perfectionism and narcissism: Testing unique relationships and gender differences. Personality and Individual Differences, 61-62, 52-56.

Shultz, J. M., Baingana, F., \&Neria, Y. (2015). The 2014 Ebola outbreak and mental health: Current status and recommended response. Journal of the American Medical Association, 313, 567-568. doi:10.1001/jama.2014.17934

Shultz, J. M., Espinel, Z., Flynn, W., Hoffmann, Y., \& Cohen, R. E. (2008). DEEP PREP: Allhazards disaster behavioral health training. Miami, FL: DEEP Center.

Smith, M. M., Sherry, S. B., Gautreau, C. M., Mushquash, A. R., Saklofske, D. H., \& Snow, S. L. (2017). The intergenerational transmission of perfectionism: Fathers' otheroriented perfectionism and daughters' perceived psychological control uniquely predict daughters' self-critical and personal standards perfectionism. Personality and Individual Differences, 119, 242-248. doi:10.1016/j.paid.2017.07.030

Smith, R. D., Keogh-Brown, M. R., \& Barnett, T. (2011). Estimating the economic impact of pandemic influenza: An application of the computable general equilibrium model to the UK. Social Science \& Medicine, 73(2), 235-244. doi:10.1016/j.socscimed.2011.05.025.

Sullivan, M. J. L., Bishop, S. R., \& Pivik, J. (1995). The Pain Catastrophizing Scale: Development and validation. Psychological Assessment, 7(4), 524-532.

Taylor, S. (2017). Clinician's guide to PTSD (2 ${ }^{\text {nd }}$ Ed.). New York: Guildford. 
SOCIAL AND PSYCHOLOGICAL CORRELATES OF THE MAJOR SOURCES OF DISCOMFORT PERCEIVED ...

Taylor, S. (2019). The psychology of pandemics. Preparing for the next global outbreak of infectious disease. Newcastle upon Tyne: Cambridge Scholars Publishing.

Tennen, H., \& Affleck, G. (1990). Blaming others for threatening events. Psychological Bulletin, 108, 209- 232.

Twenge, J. M. (2006). Generation Me: Why today's young Americans are more confident, assertive, entitled--and more miserable than ever before. New York: Atria Press.

Twenge, J. M. (2013). The evidence for generation me and against generation we. Emerging Adulthood, 1(1), 11-16.

Twenge, J. M., \& Campbell, W. K. (2007). The narcissism epidemic. Living in an age of entitlement. New York: Free Press.

Unger, K. (2007). Handbook on supported education: Providing services for students with psychiatric disabilities. Charleston SC: Book Surge Publishing.

Urbonaviciute, G., \& Hepper, E. G. (2020). When is narcissism associated with low empathy? A meta-analytic review. Journal of Research in Personality, 104036. doi: 10.1016/j.jpr. 2020.104036

van Dijk, S. D. M., Hanssen, D., Naarding, P., Lucassen, P., Comijs, H., \& Dude Voshaar, R. (2016). Big Five personality traits and medically unexplained symptoms in later life. European Psychiatry, 38, 23-30. doi:10.1016/j.eurpsy.2016.05.002

Vega, R., Ruíz-Barquín, R., Boros, S., \& Szabo, A. (2020): Could attitudes toward COVID19 in Spain render men more vulnerable than women? Global Public Health, 1278-1291. doi: 10.1080/17441692.2020.1791212

Vergara-Buenaventura, A., Chavez-Tuñon, M., \& Castro-Ruiz, C. (2020). The mental health consequences of Coronavirus disease 2019 Pandemic in dentistry. Disaster Medicine and Public Health Preparedness, 5, 1-4.

doi: 10.1017/dmp.2020.190

Wang C, Pan R, Wan X, Tan Y, Xu L, Ho CS, et al. (2020). Immediate psychological responses and associated factors during the initial stage of the 2019 coronavirus disease (COVID-19) epidemic among the general population in China. International Journal of Environmental Research and Public Health, 17, 1729.

Williamson, H. (2020). Early Effects of the COVID-19 pandemic on relationship satisfaction and attributions. Psychological Science, 31(12), 1479-1487.

doi:10.1177/0956797620972688

Winefield, H.R., Gill, T. K., Taylor, A.W., \& Pilkington, R. M. (2012). Psychological wellbeing and psychological distress: Is it necessary to measure both? Psychological Well-Being, 2, 3. https://doi.org/10.1186/2211-1522-2-3 
ÉVA KÁLLAY, SEBASTIAN PINTEA

World Health Organization. Situation report - 51. 2020.

https://www.who.int/docs/default-source/coronaviruse/situation-reports/

20200311-sitrep-51-covid-19.pdf?sfvrsn=1ba62e57_10. Accessed January $5^{\text {th }}$, 2021.

Zhu, J., Sun, L., Zhang, L., Wang, H., Fan, A., Yang, B., et al. (2020). Prevalence and influencing factors of anxiety and depression symptoms in the first-line medical staff fighting against COVID-19 in Gansu. Frontiers in Psychiatry, 11, 386. doi: 10.3389/fpsyt.2020.00386

Yang, Y., Li, W., Zhang, Q., Zhang, L., Cheung, T., \& Xiang Y. T. (2020). Mental health services for older adults in China during the COVID-19 outbreak. Lancet Psychiatry, 7(4), e19. doi: 10.1016/S2215-0366(20)30079-1

Yue, S., Zhang, J., Cao, M., \& Chen, B. (2020). Knowledge, Attitudes and Practices of COVID-19 Among Urban and Rural Residents in China: A Cross-sectional Study. Journal of Community Health, 1-6. Advance online publication. doi:10.1007/s10900-020-00877-x

Zajenkowski, M., Jonason, P. K., Leniarska, M., \& Kozakiewicz, Z. (2020). Who complies with the restrictions to reduce the spread of COVID-19? Personality and perceptions of the COVID-19 situation. Personality and Individual Differences, 166, 110-199. doi:10.1016/j.paid.2020.110199. 